\title{
Response of Soil Microbial Properties to Long-Term Application of Organic and Inorganic Amendments in a Tropical Soil (Saria, Burkina Faso)
}

\author{
Ndeye Hélène Diallo-Diagne ${ }^{1,2 *}$, Komi Assigbetse ${ }^{3,4}$, Saïdou Sall5, Dominique Masse ${ }^{3,4}$, \\ Moussa Bonzi ${ }^{6}$, Ibrahima Ndoye ${ }^{7}$, Jean Luc Chotte ${ }^{4}$ \\ ${ }^{1}$ ISRA, LEMSAT, Centre IRD-ISRA Bel Air, Dakar, Sénégal \\ ${ }^{2}$ Virginia Tech, Crop and Soil Environmental Sciences, Blacksburg, USA \\ ${ }^{3}$ IRD, UMR Eco \& Sols, LEMSAT, Centre IRD-ISRA Bel Air, Dakar, Sénégal \\ ${ }^{4} I R D$, UMR Eco \& Sols, IRD, Montpellier, France \\ ${ }^{5}$ UGB, UFR S2ATA, Saint Louis, Sénégal \\ ${ }^{6}$ INERA, Ouagadougou, Burkina Faso \\ ${ }^{7}$ UCAD, Dakar, Sénégal \\ Email: "ndeyehd1@vt.edu
}

Received 27 July 2015; accepted 19 February 2016; published 22 February 2016

Copyright (C) 2016 by authors and Scientific Research Publishing Inc.

This work is licensed under the Creative Commons Attribution International License (CC BY).

http://creativecommons.org/licenses/by/4.0/

c) (i) Open Access

\section{Abstract}

Soil microbial biomass carbon (MBC), $\beta$-glucosidase, acid phosphatase and fluorescein diacetate (FDA) activities and bacterial community structure were assessed in a long-term (26 years) experiment, at physiological stages of sorghum growth, comparing different management methods for organic (manure, straw residues) and inorganic (urea) amendments at the INERA field station in Saria (Burkina Faso). Annual application of manure led to the highest soil microbial biomass and enzyme activities. Investigations indicated that only microbial biomass and $\beta$-glucosidase activities were affected during the cropping season. Phosphatase and FDA enzyme activities did not depend on the crop development stages. The application of $\mathrm{N}$ fertilizer modified phosphatase and FDA enzyme activities, the activities being higher in soils amended with $\mathbf{N}$ fertilizer. The bacterial community structure was analyzed by PCR-denaturing gradient gel electrophoresis (PCR-DGGE) targeting the eubacterial 16S rRNA gene. Cluster analysis of PCR-DGGE patterns showed two major clusters, the first containing the mineral fertilization and straw treatments and the second, the straw + urea, manure and manure + urea treatments. Sorghum grain yields were the highest for manure treatments. In this long-term experiment, applying straw did not produce a better grain yield than that obtained in the un-amended plot.

*Corresponding author.

How to cite this paper: Diallo-Diagne, N.H., Assigbetse, K., Sall, S., Masse, D., Bonzi, M., Ndoye, I. and Chotte, J.L. (2016) Response of Soil Microbial Properties to Long-Term Application of Organic and Inorganic Amendments in a Tropical Soil (Saria, Burkina Faso). Open Journal of Soil Science, 6, 21-33. http://dx.doi.org/10.4236/ojss.2016.62003 


\title{
Keywords
}

\author{
Organic Amendments, Mineral Fertilizer, Microbial Biomass, Soil Enzyme Activities, PCR-DGGE, \\ Crop Development Stages, Lixisol
}

\section{Introduction}

In the Sudano-Sahelian region, agricultural soil productivity has been severely impaired owing to intensive cultivation, drought and soil erosion, which have led to a decrease in soil organic matter, a depletion of soil nutrients. Furthermore, in semi-arid agricultural conditions, crop residues are removed and organic input such as manure is rare. This leads to agricultural soil degradation with detrimental effects on the physical, chemical and biological properties of soil [1].

To secure rural livelihoods, soil fertility and functioning must be restored to provide sustainable farming systems. As alternative, low cost solutions for increasing soil organic matter have been proposed. Bationo et al. [2] and Badiane et al. [3] recommended regular inputs of organic amendments to soil while other authors advocated the use of improved fallows to restore organic matter to soil [4] [5]. These agricultural management methods are known to enhance the stock of soil carbon [6]. It is well established that organic matter plays a central role in maintaining key soil functions and is an essential determinant of soil fertility and resistance to erosion. Several authors have found that organic inputs increase soil microbial biomass [7]-[9] and enzyme activities [10] [11] and enhance microbial activity [12]. The application of organic amendments can, therefore, affect the activity, structure, diversity and function of soil microorganisms, which play a key role in soil processes to a greater extent than the application of inorganic fertilizers [7] [13]. All biochemical reactions in soils are mediated by the activities of enzymes and microorganisms are the major source of enzymes in soil. Microbial enzymes are involved in soil organic matter formation and decomposition and are used as indicators of soil fertility. Measurement of soil hydrolases provides an early indication of changes in soil fertility, since they are related to the mineralization of important nutrient elements and their dynamics in these systems may regulate nutrient uptake and plant growth. However, [14] suggested that some enzymes as b-glucosidase, and acid phosphatase are more sensitive to shifts in soil management and change more quickly than others. The enzyme b-Glucosidase is a common and predominant enzyme in soils and catalyzes the hydrolysis of cellobiose, and thus plays a major role in the initial phases of the decomposition of organic C compounds [15]. Acid phosphatase catalyzes the hydrolysis of a variety of organic phosphomonoesters and is therefore important in soil organic P mineralization and plant nutrition. FDA is hydrolysed by esterases, proteases and lipases, enzymes involved in the microbial decomposition of organic matter in soil [16].

The recent development of genetic techniques targeting the 16S ribosomal DNA gene or functional genes has provided an alternative to culture-based methods, providing a unique insight into the composition, richness, structure and functioning of microbial communities [17]-[19]. Denaturing gradient gel electrophoresis (DGGE) of PCR-amplified genes is one of these genetic techniques and can be used to assess the diversity of complex microbial systems [20] [21]. The great interest in determining biodiversity and function of microorganisms in agrosystems and its utilization in soil system modeling is no longer to demonstrate but there is little information on the soil microbial communities as affected by management and land uses in semiarid conditions especially for tropical regions [22]-[24] where there is rapid turnover of soil organic matter.

This paper presents the impact of the long-term application of organic amendments and inorganic fertilizers on the activity of microbial communities and the genetic structure of the total bacterial community in a 26-year experiment in semi-arid conditions in Saria (Burkina Faso). The relationships between these properties, the amendments and yields are discussed.

\section{Materials and Methods}

\subsection{Study Site}

The study was conducted in the Saria II site, a long-term field experimental site located at the Saria Agricultural Research Station $\left(12^{\circ} 16^{\prime} \mathrm{N}, 2^{\circ} 9^{\prime} \mathrm{W}, 300 \mathrm{~m}\right.$ altitude) in Burkina Faso. The climate is north-Sudanian [25] and rainfall is confined to the period from May to October with an annual mean of $800 \mathrm{~mm}$. The main species of 
natural vegetation are Parkia biglobosa, Vitellaria paradoxa, Tamarindus indica, Andropogon gayanus and Pennisetum pedicellatum. The soil is Ferric Lixisol [26]. Soil organic carbon (SOC), N and available P in soil are very low (Table 1). Since there are no carbonates in the studied soil, total $\mathrm{C}$ was assumed to be organic $\mathrm{C}$. The Cation Exchange Capacity (CEC) is poor and the soil is acid with a $\mathrm{pH}\left(\mathrm{H}_{2} \mathrm{O}\right)$ between 4.09 and 5.51.

\subsection{Experimental Design}

The experiment was set up in 1980. The treatments included in the present study are Con: control (plots without amendment); ConN: control + N fertilizer (urea, $\left.60 \mathrm{~kg} \cdot \mathrm{N} \cdot \mathrm{ha}^{-1}\right)$; Str: sorghum straw residue $\left(10 \mathrm{t} \cdot \mathrm{ha}{ }^{-1}\right)$; StrN: sorghum straw residue + urea $\left(60 \mathrm{~kg} \cdot \mathrm{N} \cdot \mathrm{ha}^{-1}\right)$; Man: animal manure $\left(10 \mathrm{t} \cdot \mathrm{ha}^{-1}\right)$; ManN: animal manure + urea $\left(60 \mathrm{~kg} \cdot \mathrm{N} \cdot \mathrm{ha}^{-1}\right)$. Each treatment was replicated six times in a randomized block design. Organic materials (manure and straw) were applied manually each year in July and incorporated into the soil. Each plot was $5.2 \mathrm{~m} \times 4$ $\mathrm{m}$. A $2 \mathrm{~m}$ strip was left between each block. The plots were ploughed after the first significant rain event to a depth of $0.2 \mathrm{~m}$. The cropping system is a continuous monoculture of sorghum (Sorghum bicolor L., cultivar Sariasso 14) with 31.250 plants ha ${ }^{-1}$ and $0.4 \mathrm{~m} \times 0.8 \mathrm{~m}$ spacing between seed-beds. The sorghum grain yield was measured in all plots from an area of $9.6 \mathrm{~m}^{2}$. The grain yield was obtained after air-drying until a constant weight was obtained.

\subsection{Soil Sampling}

Soil samples were taken after 26 years of continuous cultivation and at different stages of development of sorghum: on sowing (July), 6 weeks after sowing (August), during flowering (September) and on harvesting (November). The six replicate plots of each treatment were used as independent replicates for each analysis. For each plot, a composite soil sample was collected from the $0-10 \mathrm{~cm}$ soil layer. Field-moist soil samples were sieved $(<2 \mathrm{~mm})$ and further divided into two subsamples. The first was stored at $4{ }^{\circ} \mathrm{C}$ for microbial biomass and enzyme activities measurements performed within one month following each sampling date. The other subsamples were stored at $-20^{\circ} \mathrm{C}$ for molecular analyses.

\subsection{Microbial Biomass C}

The microbial biomass $\mathrm{C}$ was determined from $20 \mathrm{~g}$ of fresh soil by the chloroform fumigation-extraction method [27]. The microbial biomass in fumigated (10 days) and unfumigated (control) soil was quantified using ninhydrin- $\mathrm{N}$ reactive compounds extracted from soils with $1 \mathrm{M} \mathrm{KCl}$. The ninhydrin-reactive nitrogen content was determined using a continuous flow colorimeter (Evolution II, Alliance-Instrument, France). The biomass C was calculated as the increase in ninhydrin- $\mathrm{N}$ between fumigated and unfumigated soils, multiplied by 21 . The results were expressed as $\mu \mathrm{g} \cdot \mathrm{C} \cdot \mathrm{g}^{-1}$ soil.

\subsection{Enzyme Assays}

The $\beta$-glucosidase activity was assessed using $100 \mu \mathrm{l}$ of $5 \mathrm{mM}$ p-nitrophenyl- $\beta$-D-glucanopyranoside (PNG) as

Table 1. Soil characteristics, plant biomass and grain yields of the differently amended plots at Saria II experimental station, Burkina Faso. Data are Means (Standard Error) of six replicates.

\begin{tabular}{|c|c|c|c|c|c|c|}
\hline & Con & ConN & Str & StrN & Man & ManN \\
\hline Total C (mg/g) & $2.16(0.3) b$ & $2.22(0.8) \mathrm{b}$ & $2.48(0.0) \mathrm{b}$ & $2.68(0.0) b$ & $3.57(0.0) \mathrm{a}$ & $3.56(0.0) \mathrm{a}$ \\
\hline Total N (mg/g) & $0.15(0.0) \mathrm{b}$ & $0.16(0.0) \mathrm{b}$ & $0.15(0.0) \mathrm{b}$ & $0.17(0.0) \mathrm{ab}$ & $0.27(0.0) \mathrm{a}$ & $0.25(0.0) \mathrm{ab}$ \\
\hline CEC (meq/\%) & $1.95(0.3) \mathrm{a}$ & $2.24(0.7) \mathrm{a}$ & $2.13(0.6) \mathrm{a}$ & $1.99(0.4)$ a & $2.37(0.4) \mathrm{a}$ & $2.33(0.4) \mathrm{a}$ \\
\hline $\mathrm{pH} \mathrm{KCl}$ & $4.58(0.3) \mathrm{c}$ & $4.09(0.2) \mathrm{d}$ & $5.19(0.2) \mathrm{ab}$ & $4.76(0.2) \mathrm{c}$ & $5.51(0.3)$ a & $5.14(0.4) b$ \\
\hline Total P (mg/kg) & 112.67 (17.3) b & $96.83(30.2) b$ & 113.67 (15.1) b & 112.67 (20.9) b & 147.33 (19.2) a & $146.50(23.4) \mathrm{a}$ \\
\hline Available P (mg/kg) & 30.77 (4.9) bc & 28.22 (8.0) bc & 31.64 (11.9) bc & 26.19 (5.3) c & 56.37 (28.1) a & 45.53 (18.9) ab \\
\hline Grain yield (kg/ha) & 167 (174) b & 207 (124) b & $90(60) \mathrm{b}$ & 233 (154) b & 730 (319) a & 737 (350) a \\
\hline Plant biomass (kg/ha) & $480(426) b$ & $627(286) \mathrm{b}$ & 300 (192) b & $600(390) b$ & 1893 (779) a & $1900(806)$ a \\
\hline
\end{tabular}

Means followed by the same letter in the same rows do not differ significantly $(\mathrm{P}<0.05)$. 
the substrate [28]. Soil subsamples (100 mg of fresh soil) were incubated at $37^{\circ} \mathrm{C}$ for $2 \mathrm{~h}$ with $400 \mu \mathrm{l}$ of citrate phostphate buffer at $\mathrm{pH}$ 5.8. The p-nitrophenol (p-NP) produced in the enzymatic reactions was extracted and determined at $400 \mathrm{~nm}$. The results were expressed as $\mu \mathrm{g} \mathrm{p}-\mathrm{NP}$ released $\mathrm{g}^{-1} \cdot \mathrm{soil}^{-1} \mathrm{~h}^{-1}$. Acid phosphatase activity was determined using p-nitrophenyl phosphate disodium (p-NPP, $5 \mathrm{mM}$ ) as substrate [29]. Fresh soil (100 mg) was incubated at $37^{\circ} \mathrm{C}$ for $1 \mathrm{~h}$ with $0.5 \mathrm{M}$ sodium acetate buffer at $\mathrm{pH} 6$ and $100 \mu \mathrm{l}$ of substrate [30]. The p-nitrophenol (p-NP) formed was determined by spectrophotometry at $400 \mathrm{~nm}$ and the results were expressed as $\mu \mathrm{g}$ p-NP released $\mathrm{g}^{-1} \cdot \mathrm{soil}^{-1} \mathrm{~h}^{-1}$. The fluorescein diacetate activity (FDA) was determined using the method described by Adam and Duncan [31]. A $1 \mathrm{~g}$-fresh soil was exposed to $200 \mu \mathrm{l}$ of FDA solution (FDA $1 \mathrm{mg} \cdot \mathrm{ml}^{-1}$ and phosphate potassium buffer, $60 \mathrm{mM}$ ) at $\mathrm{pH} 7.6$ for $1 \mathrm{~h}$ at $30^{\circ} \mathrm{C}$. Measurements were taken at $490 \mathrm{~nm}$ and the results were expressed as $\mu \mathrm{g}$ fluorescein released $\mathrm{g}^{-1} \cdot$ soil $^{-1} \mathrm{~h}^{-1}$.

\subsection{Bacterial Community Structure Analysis}

Molecular analyzes were limited to 4 replicates per sample in order to reduce their related cost. Total DNA extraction was done as described by Hai et al. [32]. The extractions were performed using "Precellys-Keramik-Kit" lysing tubes (PEQLAB Biotechnologie GmbH, Germany) and the suspensions were then subjected to bead beating (BeadBeater, Biospec Products). DNA concentrations were measured and checked for the presence of potential PCR inhibitors using a NanoDrop fluorospectrophotometer (NanoDrop Technologies, Delaware, USA).

PCR-denaturing gradient gel electrophoresis (PCR-DGGE): The V3 region of the 16S rRNA gene was amplified for denaturing gradient gel electrophoresis analysis using primers UNIV518r [33] and EUB338f with a 40-bp GC clamp at the 5' end [34]. A touchdown PCR was performed in $25 \mu \mathrm{l}$ containing $2.5 \mathrm{ng}$ ADN, Taq Polymerase Ready-To-Go (Amersham-Bioscienes, France) and $0.5 \mu \mathrm{M}$ of each primer. The thermal profile for amplification was as follows: $5 \mathrm{~min}$ at $94^{\circ} \mathrm{C} ; 20$ cycles of $30 \mathrm{~s}$ at $94^{\circ} \mathrm{C}, 30 \mathrm{~s}$ at $65^{\circ} \mathrm{C}$ (the annealing temperature decreased by $0.5^{\circ} \mathrm{C}$ at every cycle), and $1 \mathrm{~min}$ at $72^{\circ} \mathrm{C}$. The additional 10 cycles were run at an annealing temperature of $55^{\circ} \mathrm{C}$. The PCR products were electrophoresed on $1.5 \%(\mathrm{w} / \mathrm{v})$ agarose gels and stained for 30 min with ethidium bromide $\left(1 \mathrm{mg} \cdot \mathrm{L}^{-1}\right)$. For DGGE analysis, the amplified products $(20 \mu \mathrm{l})$ were separated with the Ingeny U-Phor system (Ingeny, Goes, The Netherlands) in 8\% polyacrylamide (acrylamide-bisacrylamide [37.5:1]) gel containing a linear $45 \%$ to $70 \%$ denaturant gradient (100\% denaturant contained $7 \mathrm{M}$ urea and $40 \%$ formamide). Electrophoresis was carried out using $1 \mathrm{X}$ Tris-acetate-EDTA buffer at $100 \mathrm{~V}$ and $60^{\circ} \mathrm{C}$ for $17 \mathrm{~h}$. Gels were stained for $30 \mathrm{~min}$ with ethidium bromide $\left(1 \mathrm{mg} \cdot \mathrm{L}^{-1}\right)$ and destained in distilled water for $10 \mathrm{~min}$. The banding patterns were then photographed using a Vilber Lourmat gel imaging system (Vilber Lourmat, France). Band detection and their intensity quantification were performed using TotalLab gel imaging software (Nonlinear Dynamics Ltd., Newcastle UK), with manual checking and adjustment of each band position. The richness index (R) was calculated with the assumption that each band was an operational taxonomic unit (OTU). Band intensity was used as an indication of relative abundance. The clustering of the DGGE patterns analyzed using TotalLab was performed using the Unweighted Pair Group method with Mathematical Average (UPGMA). The structural diversity of the microbial community was estimated by the Shannon index of general diversity [35] based on the number of bands present and the relative intensities of the bands in each lane. The intensity of the bands was estimated from the peak heights. The Shannon $\mathrm{H}$ index was calculated using the following equation:

$$
H=-\sum(P i * \log P i)
$$

where $P i$ is $n i / N$; $n i$ is the peak height and $N$ is the sum of all peak heights.

\subsection{Statistical Analyses}

The differences between treatments were estimated by three-way analysis of variance using XLSTAT 2010 software and the Fischer Least Significant Difference (LSD) test at 5\% level used to determine whether the sampling date, treatment, nitrogen input and possibly interaction between them had any significant influence. Pearson correlation coefficients were used to assess relationships between selected soil variables. All results were significant when $\mathrm{P}<0.05$.

\section{Results}

\subsection{Sorghum Grain Yields and Plant Biomass}

Grain yields ranged from $167 \mathrm{~kg} \cdot \mathrm{ha}^{-1}$ to $737 \mathrm{~kg} \cdot \mathrm{ha}^{-1}$ (Table 1). Significantly higher yields were obtained in 
soils amended with manure and manure $+\mathrm{N}$-fertilizer $(\mathrm{P}<0.001)$. No significant difference was noticed between straw-amended soils (Str and StrN) and control soils (Con and ConN). Highest plant biomass yields (Table 1) were obtained from the manure-amended plots $(\mathrm{P}<0.001)$. Interestingly, straw amendment reduced plant biomass yields $\left(300 \mathrm{~kg} \cdot \mathrm{ha}^{-1}\right)$ compared to the untreated control $\left(480 \mathrm{~kg} \cdot \mathrm{ha}^{-1}\right)$.

\subsection{Microbial Biomass and Enzyme Activities}

The results regarding microbial biomass and enzyme activities are shown in Table 2. The three-way analysis of

Table 2. The effect of long term fertilization on microbial biomass and enzymatic activities in soils collection at the four sampling seasons. Data are means (standard error) of six replicates

\begin{tabular}{|c|c|c|c|c|c|c|}
\hline \multirow{2}{*}{ Date } & \multicolumn{6}{|c|}{ Treatment } \\
\hline & Con & ConN & Str & StrN & Man & ManN \\
\hline \multicolumn{7}{|l|}{$\begin{array}{l}\text { Microbial biomass } \\
\left(\mathrm{mg} \cdot \mathrm{C} \cdot \mathrm{kg}^{-1} \cdot \text { soil }\right)\end{array}$} \\
\hline & Con & ConN & Str & StrN & Man & ManN \\
\hline Sowing & $29.72(0.87)$ & $25.88(1.81)$ & $41.6(2.84)$ & $38.44(1.42)$ & 49.88 (1.07) & $49.88(1.41)$ \\
\hline 6 weeks & 33.05 (1.77) & 31.00 (1.27) & $47.11(2.43)$ & 42.38 (2.78) & $52.55(1.44)$ & 51.51 (1.33) \\
\hline Flowering & $17.27(2.72)$ & $26.16(2.10)$ & $11.61(1.18)$ & 27.55 (3.62) & 15.33 (3.69) & 19.77 (2.08) \\
\hline Harvested & $4.94(0.44)$ & $5.88(0.67)$ & $6.16(0.65)$ & $4.16(0.30)$ & $6.5(0.70)$ & $8.6(0.87)$ \\
\hline \multicolumn{7}{|l|}{$\begin{array}{l}\text { Phosphatase } \\
\left(\mu g \cdot \text { PNP }^{-1} \cdot{ }^{-1} \cdot \text { soil }^{\prime} h^{-1}\right)\end{array}$} \\
\hline Sowing & 85.87 (2.0) & 92.23 (4.5) & $119.29(4.0)$ & $127.72(4.2)$ & $127.75(5.0)$ & $146.03(4.0)$ \\
\hline 6 weeks & 85.34 (4.9) & $85.73(2.5)$ & $109.34(2.8)$ & $112.42(4.5)$ & 109.35 (1.3) & $141.89(5.4)$ \\
\hline Flowering & 91.02 (4.6) & $102.86(7.7)$ & $113.33(5.4)$ & $146.80(7.6)$ & $124.53(7.4)$ & $158.89(7.1)$ \\
\hline Harvested & 73.20 (2.8) & 91.96 (4.3) & $104.17(3.4)$ & $109.75(2.8)$ & $114.16(4.3)$ & 131.75 (3.4) \\
\hline \multicolumn{7}{|l|}{$\begin{array}{l}\text { B-glucosidase } \\
\left(\mu \mathrm{g} \cdot \mathrm{PNP} \cdot \mathrm{g} \cdot{ }^{-1} \cdot \mathrm{soil} \cdot \mathrm{h}^{-1}\right)\end{array}$} \\
\hline Sowing & $9.87(0.7)$ & $6.70(0.6)$ & $14.55(0.5)$ & $12.49(0.3)$ & $15.71(0.4)$ & $15.62(0.5)$ \\
\hline 6 weeks & $8.41(0.6)$ & $7.24(1.0)$ & $14.09(0.6)$ & $14.34(0.6)$ & $18.05(0.7)$ & $16.85(0.7)$ \\
\hline Flowering & $9.82(0.8)$ & $6.21(0.5)$ & $14.46(0.8)$ & $19.76(0.8)$ & 22.13 (1.3) & $18.97(0.6)$ \\
\hline Harvested & 16.84 (0.9) & $21.27(2.0)$ & $17.29(0.7)$ & 16.95 (1.3) & $24.61(0.7)$ & $19.30(0.7)$ \\
\hline \multicolumn{7}{|l|}{$\begin{array}{l}\text { Fluorescein diacetate } \\
\left(\mu \mathrm{g} \cdot \mathrm{fl} \cdot \mathrm{g}^{-1} \cdot \mathrm{soil}^{\left.-\mathrm{h}^{-1}\right)}\right.\end{array}$} \\
\hline Sowing & $0.86(0.0)$ & $0.81(0.0)$ & $1.32(0.0)$ & $1.80(0.1)$ & $1.37(0.0)$ & $2.07(0.0)$ \\
\hline 6 weeks & $1.35(0.1)$ & $1.85(0.1)$ & $2.65(0.1)$ & $3.25(0.1)$ & $3.65(0.1)$ & $3.79(0.1)$ \\
\hline Flowering & $1.30(0.0)$ & $1.75(0.0)$ & $1.63(0.1)$ & $2.70(0.1)$ & $2.94(0.2)$ & $3.20(0.2)$ \\
\hline Harvested & $1.17(0.0)$ & $1.74(0.1)$ & $1.84(0.1)$ & $1.98(0.1)$ & $2.51(0.1)$ & $2.59(0.0)$ \\
\hline \multirow[t]{2}{*}{ Source of variation } & $d f$ & $\begin{array}{c}\text { Microbial } \\
\text { Biomass }\end{array}$ & Phosphatase & B-glucosidase & $\begin{array}{l}\text { Fluorescein } \\
\text { diacetate }\end{array}$ & \\
\hline & \multicolumn{6}{|c|}{$\mathrm{P}(<0.05)$} \\
\hline Date & 3 & $<0.0001$ & 0.037 & $<0.0001$ & $<0.0001$ & \\
\hline Input management & 2 & 0.000 & $<0.0001$ & $<0.0001$ & $<0.0001$ & \\
\hline $\mathrm{N}$ fertilizer & 1 & ns & 0.002 & ns & 0.002 & \\
\hline Date*input management & 6 & 0.001 & ns & 0.024 & ns & \\
\hline Date $* N$ fertilizer & 3 & ns & ns & ns & ns & \\
\hline Input management $* \mathrm{~N}$ fertilizer & 2 & ns & ns & ns & ns & \\
\hline $\begin{array}{l}\text { Date*input management } * \mathrm{~N} \\
\text { fertilizer }\end{array}$ & 6 & ns & ns & ns & ns & \\
\hline
\end{tabular}


variance carried out on the data allowed us to show the effect of the organic management, $\mathrm{N}$ fertilizer and the sampling date on microbial biomass and enzyme activities. There was an interaction between the sampling date and the organic management on microbial biomass and $\beta$-glucosidase activity. Application of $\mathrm{N}$ fertilizer had not modified these parameters. Overall, organic management had an effect at the first two sampling dates, at the time of sowing and 6 weeks later. In these cases values of microbial biomass were significantly $(\mathrm{P}<0.05)$ higher than that of the controls and the assessment of the differences show: $44 \%$ for straw and $79 \%$ for manure at the time of sowing and $40 \%$ for straw and $62 \%$ for manure 6 weeks after sowing. The microbial biomass dropped considerably from flowering to an average of $6.01 \mu \mathrm{g} \cdot \mathrm{g}^{-1}$ at harvest, a factor of 6.5 times less than the overall average measured at the time of sowing. $\beta$-glucosidase activity increased significantly $(\mathrm{P}<0.05)$ with the addition of manure or straw with respect to the control at the first three sampling dates. This difference was no longer significant at the final sampling (harvest).

Regarding phosphatase and FDA activities, there was no significant interaction between the date, organic management and $\mathrm{N}$ fertilizer application. The maximum values for these variables were for samples taken at the time of sowing and, above all, during flowering. Adding manure also resulted in an average increase of $49 \%$ for phosphatase and 104\% for FDA relative to the control, regardless of the sampling date or the addition of N fertilizer. Adding straw had a lesser effect with an average increase of 33\% for phosphatase and 59\% for FDA relative to the control. Adding $\mathrm{N}$ increased phosphatase by $13 \%$ and FDA by $22 \%$ for FDA relative to plots without $\mathrm{N}$ fertilizer addition.

\subsection{Bacterial Community Structure}

The DGGE of the 16S rRNA amplified from all of the treatments displayed different patterns. The clustering method revealed two major clusters at sowing, 6 weeks and harvest sampling time (Figure 1). Cluster 1 groups the soil amended with manure (Man and ManN) and straw plus $\mathrm{N}$ fertilizer (StrN), while the control (Con, and ConN) and soil amended with straw (Str) are grouped in cluster 2. However, this differentiation was less evident for samples taken during flowering. There was less difference in the community structure in StrN and Man amended soils than in the straw and control treatments. The patterns had some common and dominant bands indicating that there were common bacterial types in the soils regardless of the type of amendment applied and the plant development stage.

Globally the richness $\mathrm{R}$ index and the Shannon-Weaver diversity index $(\mathrm{H})$ had the same trend and showed that the microbial diversity varied with the type of soil management and generally increased with the application of manure (Table 3$)$. Microbial diversity varied significantly $(\mathrm{P}<0.05)$ with the sorghum development stages with the lowest values recorded at flowering.

\subsection{Correlation between the Microbial Biomass, Enzyme Activities and Shannon's Diversity}

Correlation coefficients between microbial biomass, enzyme activities and the Shannon diversity were calculated (Table 4) and revealed distinct variation during the different sorghum development stages. At sowing a negative correlation was observed between Shannon's diversity and microbial biomass $(P=0.003)$ and FDA (P $=0.011)$ whereas positive correlations were found between microbial biomass and phosphatase $(\mathrm{P}<0.0001)$, FDA ( $\mathrm{P}<0.0001), \beta$-glucosidase $(\mathrm{P}=0.000)$ activities at this date and 6 weeks sampling date. At flowering the Shannon's diversity and enzyme activities (phosphatase $\mathrm{P}=0.002)$, FDA $(\mathrm{P}=0.001), \beta$-glucosidase $(\mathrm{P}=0.007)$ were correlated. At harvest time only FDA and Phosphatase were positively correlated $(\mathrm{P}<0.0001)$.

\section{Discussion}

Long-term fertilization had a significant effect on soil organic $\mathrm{C}$, total $\mathrm{N}$ content, total $\mathrm{P}$ and $\mathrm{pH}$. The highest values of soil organic $\mathrm{C}$, total $\mathrm{N}$ content, total $\mathrm{P}$ were recorded in soils amended with organic manure. Similar effects were shown in previous long-term field studies using comparable organic amendments. Masto et al. [10], Chu et al. [7] and Liu et al. [23] showed that organic manure significantly increased the amount of soil organic C and total N. Mandal et al. [36] and Enwall et al. [37] on a long-term application site (34 and 51 years) have recorded a significant increase in organic $\mathrm{C}$ and total $\mathrm{N}$ for amendment with farmyard manure with NPK. The application of organic amendments (manure or sewage sludge) generally increased the SOM content to a much greater extent than that of inorganic fertilizer [23] [37] [38]. 

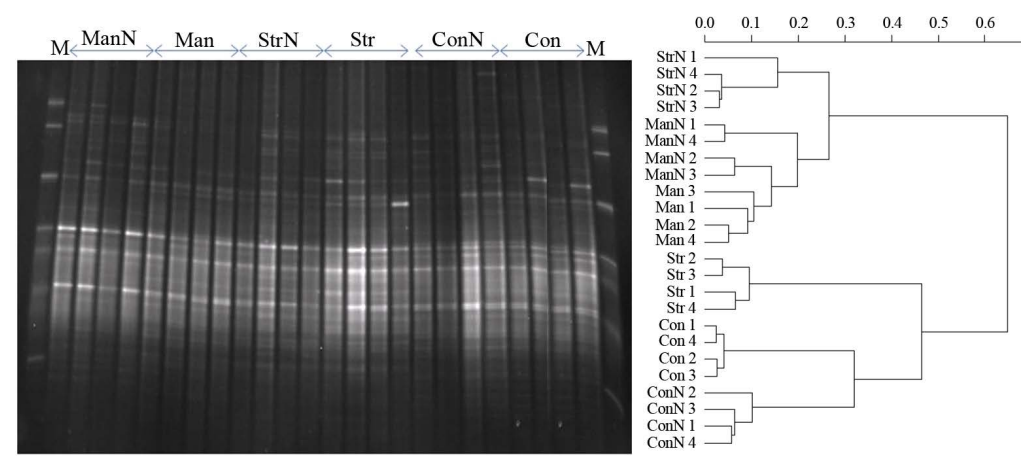

(a)
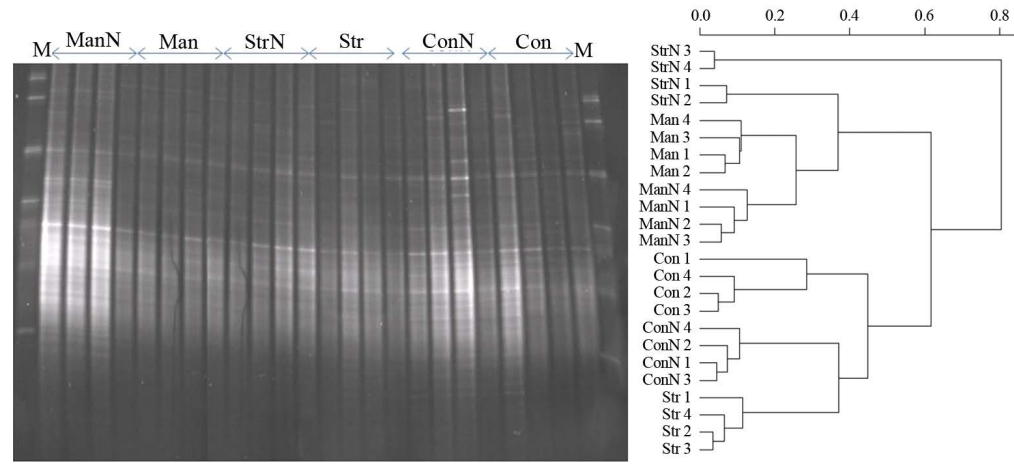

(b)
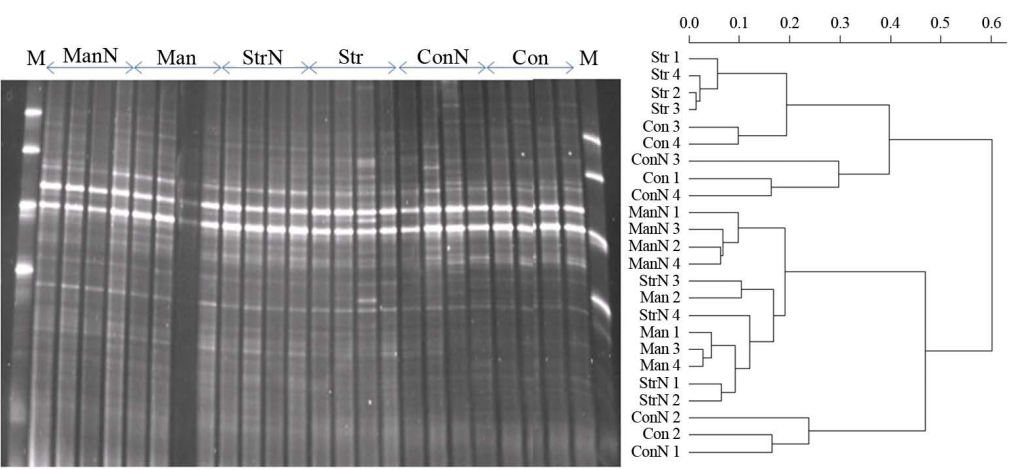

(c)
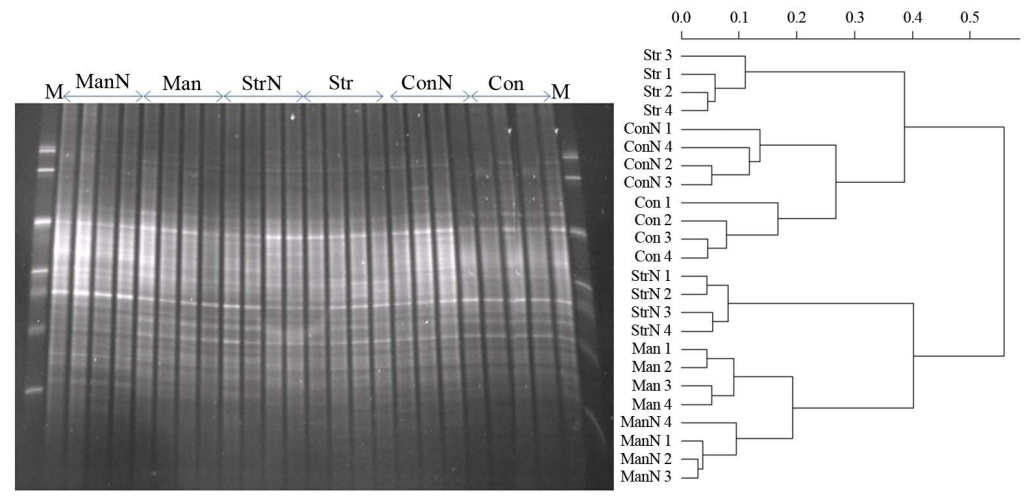

(d)

Figure 1. Profiles and UPGMA dendrogram describing pattern similarities of DGGE profiles obtained from treatments at different growth stages. (a) sowing, (b) 6 weeks after sowing, (c) flowering, (d) harvested; Con: control, ConN: control + urea, Str: straw, StrN: straw + urea, Man: manure, ManN: manure + urea. 
Table 3. Species richness $(\mathrm{R})$ and Shannon diversity $(\mathrm{H})$ indexes values for DGGE profiles from soils collection at the four sampling date.

\begin{tabular}{ccccccccc}
\hline & \multicolumn{7}{c}{ R } & \multicolumn{3}{c}{$\mathrm{H}$} \\
\hline Con & Sowing & 6 weeks & Flowering & Harvested & Sowing & 6 weeks & Flowering & Harvested \\
\hline ConN & ${ }^{\mathrm{B}} 23.00 \mathrm{c}$ & ${ }^{\mathrm{A}} 25.75 \mathrm{~b}$ & ${ }^{\mathrm{C}} 13.50 \mathrm{~d}$ & ${ }^{\mathrm{B}} 22.50 \mathrm{c}$ & ${ }^{\mathrm{A}} 1.30 \mathrm{c}$ & ${ }^{\mathrm{A}} 1.31 \mathrm{bc}$ & ${ }^{\mathrm{B}} 1.08 \mathrm{c}$ & ${ }^{\mathrm{A}} 1.32 \mathrm{~b}$ \\
Str & ${ }^{\mathrm{A}} 25.00 \mathrm{a}$ & ${ }^{\mathrm{A}} 24.00 \mathrm{c}$ & ${ }^{\mathrm{C}} 13.25 \mathrm{~d}$ & ${ }^{\mathrm{B}} 20.25 \mathrm{~d}$ & ${ }^{\mathrm{A}} 1.36 \mathrm{a}$ & ${ }^{\mathrm{A}} 1.35 \mathrm{ab}$ & ${ }^{\mathrm{C}} 1.06 \mathrm{c}$ & ${ }^{\mathrm{B}} 1.27 \mathrm{c}$ \\
StrN & ${ }^{\mathrm{A}} 25.00 \mathrm{a}$ & ${ }^{\mathrm{B}} 22.00 \mathrm{~d}$ & ${ }^{\mathrm{D}} 15.00 \mathrm{c}$ & ${ }^{\mathrm{C}} 20.50 \mathrm{~d}$ & ${ }^{\mathrm{B}} 1.34 \mathrm{ab}$ & ${ }^{\mathrm{C}} 1.29 \mathrm{~cd}$ & ${ }^{\mathrm{D}} 1.14 \mathrm{~b}$ & ${ }^{\mathrm{A}} 1.40 \mathrm{a}$ \\
Man $23.75 \mathrm{~b}$ & ${ }^{\mathrm{C}} 20.50 \mathrm{e}$ & ${ }^{\mathrm{C}} 21.00 \mathrm{~b}$ & ${ }^{\mathrm{A}} 27.00 \mathrm{a}$ & ${ }^{\mathrm{A}} 1.33 \mathrm{ab}$ & ${ }^{\mathrm{C}} 1.25 \mathrm{~d}$ & ${ }^{\mathrm{C}} 1.24 \mathrm{a}$ & ${ }^{\mathrm{B}} 1.28 \mathrm{c}$ \\
ManN & ${ }^{\mathrm{B}} 23.00 \mathrm{c}$ & ${ }^{\mathrm{A}} 28.00 \mathrm{a}$ & ${ }^{\mathrm{C}} 19.75 \mathrm{~b}$ & ${ }^{\mathrm{B}} 24.00 \mathrm{~b}$ & ${ }^{\mathrm{C}} 1.31 \mathrm{bc}$ & ${ }^{\mathrm{A}} 1.36 \mathrm{a}$ & ${ }^{\mathrm{D}} 1.23 \mathrm{a}$ & ${ }^{\mathrm{B}} 1.33 \mathrm{~b}$ \\
\hline
\end{tabular}

Means $(n=4)$ within columns followed by the same letter are not significantly different $(P<0.05)$. Capital letters indicate significant difference in the same row $(\mathrm{P}<0.05)$.

Table 4. Correlation matrix of pearson $(\mathrm{P}<0.05)$ of microbial biomass, enzymes activities and Shannon index diversity enzymes activities.

\begin{tabular}{|c|c|c|c|c|c|}
\hline Variables & Shannon H & Biomasse & Phosphatase & B-glucosidase & FDA \\
\hline \multicolumn{6}{|l|}{ Sowing } \\
\hline Shannon H & 1 & & & & \\
\hline Biomasse & $-0.65^{* * *}$ & 1 & & & \\
\hline Phosphatase & ns & $0.75^{* * *}$ & 1 & & \\
\hline B-glucosidase & ns & $0.67^{* * *}$ & $0.61^{* *}$ & 1 & \\
\hline FDA & $-0.49^{*}$ & $0.78^{* * *}$ & $0.85^{* * *}$ & $0.49^{*}$ & 1 \\
\hline \multicolumn{6}{|l|}{$\underline{6 \text { weeks }}$} \\
\hline Shannon H & 1 & & & & \\
\hline Biomasse & ns & 1 & & & \\
\hline Phosphatase & ns & $0.71^{* * *}$ & 1 & & \\
\hline B-glucosidase & ns & $0.46^{*}$ & $0.62^{* *}$ & 1 & \\
\hline FDA & ns & $0.74^{* * *}$ & $0.73^{* * *}$ & $0.71^{* * *}$ & 1 \\
\hline \multicolumn{6}{|l|}{ Flowering } \\
\hline Shannon H & 1 & & & & \\
\hline Biomasse & ns & 1 & & & \\
\hline Phosphatase & $0.56^{* *}$ & ns & 1 & & \\
\hline B-glucosidase & $0.65^{* *}$ & ns & $0.57^{* *}$ & 1 & \\
\hline FDA & $0.50^{*}$ & ns & ns & ns & 1 \\
\hline \multicolumn{6}{|l|}{ Harvest } \\
\hline Shannon H & 1 & & & & \\
\hline Biomasse & ns & 1 & & & \\
\hline Phosphatase & ns & ns & 1 & & \\
\hline B-glucosidase & ns & ns & ns & 1 & \\
\hline FDA & ns & ns & $0.86^{* * *}$ & ns & 1 \\
\hline
\end{tabular}

Coefficients higher than 0.70 are in bold NS Not significant, ${ }^{*} \mathrm{P}<0.05,{ }^{* *} \mathrm{P}<0.01,{ }^{* * *} \mathrm{P}<0.001$. 
This study showed that $\mathrm{N}$ input through amendment with urea significantly decreased the soil $\mathrm{pH}$. This could be attributable to the repeated application of inorganic fertilizers as is the case in Saria. This acidifying effect of $\mathrm{N}$-fertilizer is in agreement with the findings of Hati et al. [39] and Liu et al. [23]. As agricultural use of inorganic fertilizers unavoidably increases soil acidity, Ge et al. [40] recommended that the combined use of organic manure with inorganic fertilizers should be considered depending on the balance between crop demand and the supply of available nutrients in the soil.

Microbial biomass has often been used to assess the effect of different farming systems on soil fertility [41]. In this study, the microbial biomass (MBC) varied according to the sorghum developmental stage. High values were recorded at sowing and 6 weeks after sowing, which were periods with heavy rainfall. Long-term application of organic manure significantly increased the biomass $C$ at the various sampling times, followed by amendment with straw. This result is consistent with previous findings of Gu et al. [9] and Liu et al. [23] who observed that the microbial biomass was considerably greater in soils receiving manure along with NPK fertilizer than in plots receiving only inorganic fertilizer. This increase in microorganisms might be explained by the source of easily degradable compounds through the addition of organic matter in the oligotrophic soil environment [42]. Previous studies [38] [43] reported that farming systems using green manures, manure and crop rotation to provide carbon inputs produced higher total microbial biomass than the systems using only inorganic fertilizers. These carbon rich materials can sustain microbial activity and growth, thus enhancing biogeochemical nutrient cycles [44]. The decreased MBC content after inorganic fertilizer application is also consistent with several previous reports [22] [45] [46]; it could be explained by the acidifying effect of mineral N.

Houot and Chaussod [47] found a positive correlation between microbial biomass and C content on a 80-year corn/beet rotation site with various types and levels of fertilization. Organic amendment was also reported to increase enzyme activities in soil [48] [49]. The presence and activity of living beings in the soil result in the synthesis of enzymes. Enzymes play a key role in the nutrient cycle. Our results showed that extracellular enzymes (acid phosphatase, $\beta$-glucosidase, FDA) were enhanced by organic amendments, especially manure. The differences in these activities may be related to the soil properties such as carbon content and microbial biomass [10] [24]. The enzyme activities studied in this work (phosphatase, $\beta$-glucosidase and fluorescien diacetate) had different activity peaks: 6 weeks after sowing for FDA, flowering for phosphatase and on harvesting for $\beta$-glucosidase. This could be explained by the nature of their substrates. The FDA hydrolysis rate is widely accepted as an accurate method for measuring total microbial activity in soils [31] because FDA hydrolysis is mediated simultaneously by protease, esterase and lipase and it can reflect the activities of these enzymes in soil [50] [51]. FDA activity showed clear seasonal variation with the highest value 6 weeks after sowing correlated with the highest microbial biomass. The reduction of FDA on flowering and harvest may be attributed to the lower uptake of fluorescein diacetate by soil microbial cells owing to high drying stress and the destruction of enzymes such as protease. The $\beta$-glucosidase and phosphatase activities in soils have been found to be persistent for long periods owing to some form of enzyme protective mechanism existing in soils, for example bound to soil colloids and humic substances, free in soil solutions or associated with living or dead plants or microbial cells. These mechanisms may protect those enzymes against external factors such as desiccation. Our result suggests enrichment in soil litter of a cellulolitic [52] which acts as substrate for the enzymes at a later stage.

Molecular fingerprinting (DGGE) was used to examine the effects of long-term fertilization regimes on bacterial community structure. These results showed that long-term organic and inorganic fertilization had different effects on the genetic structure of the total bacterial community. The different treatments displayed different DGGE profiles. Nannipieri et al. [53] defined microbial diversity as a general term used to include genetic diversity, that is, the amount and distribution of genetic information, within microbial species. This DGGE technique allows to analyze many samples at a same time and to compare the communities during environmental modifications [20] [54]. DGGE technique take account alive and dead microorganisms that can cause extracellular enzymes found in the soil of which a correlation Shannon and enzyme activities is possible. The correlation between soils parameters showed that soil functioning and diversity vary according to the plant growth steps. Microbial biomass and enzyme activities were correlated at sowing and at the early stage of plant development. Greater enzyme activities could be related to greater production of enzymes by the increased microbial biomass [55]. Positive correlations between them support this view. At flowering, the correlations between diversity and microbial activities suggest that for this period known for much exudation and rhizodeposition, microbial activity could be linked to the diversity of microbial communities and not the density. Results showed that no direct relationship exists between the microbial properties, activities and community structure. However, the differ- 
ences in response to the amendments suggest that microbial function and community structure reflect the microbial diversity. The differences in the microbial activity or function might be reflected in changes in community structure.

Changes in microbial activity and composition can in turn influence plant growth by increasing nutrient turnover. In practice, the crop yield is the result of all the physical, chemical, biological interactions in the soil. Results showed that the manure-amended plots displayed the highest grain yield indicating the benefits of organic manure on crop growth. These results are consistent with those obtained in long-term fertilizer experiments by Hati et al. [39], Bi et al. [56] and Liu et al. [23]. However, straw-amendment did not stimulate grain yield. Moreover, no significant difference was measured between $\mathrm{N}$ fertilized and unfertilized treatments. Mando et al. [24], investigating the same field experiment, obtained different results when comparing grain yields measured for the various treatments in 1999, 2000, 2001 and 2002. Their results also showed that soil amended with manure exhibited the highest grain yields, but they found that the application of straw led to higher grain biomass than that of the control soil. Moreover, they observed a significant positive impact of the application of $\mathrm{N}$ fertilizer in combination with straw. It seemed that the positive impact of straw recorded up to 2002 was no longer significant compared to un-amended soil in 2006. This result may be explained by the fact that organic materials such as cereal residues may have a strong influence on the immobilization of inorganic N [57] [58] and may release allelopathic compounds in soils [59] [60], thereby affecting crop yields. A reduction in yield following straw addition has been reported in several works [61] [62].

\section{Conclusion}

This study, in one of the few long-term experimental sites in a tropical environment with semi-arid climate, complements previously published works [24]. It provides additional information by comparing the effect of repeated annual amendments of crop residues and manure with or without urea on the soil biological components. The higher microbial abundance, enzyme activities and soil bacteria diversity recorded with manure application reflected a better substrate and nutrient cycling capacity compared to other treatments. Long term fertilization of sorghum straw does not reveal an improvement in grain yields compared to mineral fertilized and control plots. This result shows that it is important to characterize the processes for release and mineralization of nutrients more clearly depending on the nature of the resources available for farmers.

\section{Acknowledgements}

This research was supported by ANR funds (ANR-Biodiversité-2005, Programme Microbes). We gratefully acknowledge Dr Armand koné for constructive comments on the manuscript.

\section{References}

[1] Rivero, C., Chirenje, T., Ma, L.Q. and Martinez, G. (2004) Influence of Compost on Soil Organic Matter Quality under Tropical Conditions. Geoderma, 123, 355-361. http://dx.doi.org/10.1016/j.geoderma.2004.03.002

[2] Bationo, A., Lompo, F. and Koala, S. (1998) Research on Nutrient Flows and Balances in West Africa: State-of-theArt. In: Smaling, E.M.A., Ed., Nutrient Balances as Indicators of Production and Sustainability in Sub-Saharan African Agricultural, Agriculture, Ecosystems \& Environment, 71, 19-36.

[3] Badiane, A.N., Khouma, M. and Sene, M. (2000) Région de Diourbel: Gestion des sols. Drylands Research Working Paper 15, Drylands Research, Somerset, 25 p.

[4] Floret, C. and Pontanier, R. (1993) Recherches sur la jachère en Afrique tropicale, In: Floret, C., Pontanier, R. and Serpentié, G., Eds., La Jachère en Afrique Tropicale, Mab UNESCO, 11-54.

[5] Manlay, R.J. (2000) Organic Matter Dynamics in Mixed-Farming Systems of the West African Savanna: A Village Case Study from South Senegal. Ph.D. Thesis, ENGREF, Paris, 278 p.

[6] Roldan, A., Salinas-Garcia, J.R., Alguacil, M.M. and Caravaca, F. (2005) Changes in Soil Enzyme Activity, Fertility, Aggregation and C Sequestration Mediated by Conservation Tillage Practices and Water Regime in a Maize Field. Applied Soil Ecology, 30, 11-20. http://dx.doi.org/10.1016/j.apsoil.2005.01.004

[7] Chu, H.Y., Lin, X.G., Fujii, T., Morimotob, S., Yagi, K., Hu, J.L. and Zhang, J.B. (2007) Soil Microbial Biomass, Dehydrogenase Activity, Bacterial Community Structure in Response to Long-Term Fertilizer Management. Soil Biology \& Biochemistry, 39, 2971-2976. http://dx.doi.org/10.1016/j.soilbio.2007.05.031

[8] Koné, W.A., Tondoh, E.J., Angui, K.T.P., Bernhard-Reversat, F., Loranger-Merciris, G., Brunet, D. and Brédoumi, 
K.S.T. (2008) Is Soil Quality Improvement by Legume Cover Crops a Function of Initial Soil Chemical Characteristics? Nutrient Cycling in Agroecosystems, 82, 89-105. http://dx.doi.org/10.1007/s10705-008-9172-4

[9] Gu, Y., Zhang, X., Tu, S. and Lindström, K. (2009) Soil Microbial Biomass, Crop Yields, and Bacterial Community Structure as Affected by Long-Term Fertilizer Treatments under Wheat-Rice Cropping. European Journal of Soil Biology, 45, 239-246. http://dx.doi.org/10.1016/j.ejsobi.2009.02.005

[10] Masto, R.E., Chhonkar, P.K., Singh, D. and Patra, A.K. (2006) Changes in Soil Biological and Biochemical Characteristics in a Long-Term Field Trial on a Sub-Tropical Inceptisol. Soil Biology \& Biochemistry, 38, 1577-1582. http://dx.doi.org/10.1016/j.soilbio.2005.11.012

[11] Koné, W.A., Edoukou, E.F., Gonnety, T.J., N’Dri, A.A.N., Assémien, E.F.L., Angui, K.T.P. and Tondoh, E.J. (2012) Can the Shrub Chromolaena odorata (Asteraceae) Be Considered as Improving Soil Biology and Plant Nutrient Availability. Agroforestry Systems, 85, 233-245. http://dx.doi.org/10.1007/s10457-012-9497-5

[12] Hungria, M., Franchini, J.C., Brandao-Junior, O., Kaschuk, G. and Souza, R.A. (2009) Soil Microbial Activity and Crop Sustainability in a Long-Term Experiment with Three Soil-Tillage and Two Crop-Rotation Systems. Applied Soil Ecology, 42, 288-296. http://dx.doi.org/10.1016/j.apsoil.2009.05.005

[13] Lejon, D.P.H., Sebastia, J., Lamy, I., Chaussod, R. and Ranjard, L. (2007) Relationships between Soil Organic Status and Microbial Community Density and Genetic Structure in Two Agricultural Soils Submitted to Various Types of Organic Management. Microbial Ecology, 53, 650-663. http://dx.doi.org/10.1007/s00248-006-9145-6

[14] Green, V.S., Stott, D.E., Cruz, J.C. and Curi, N. (2007) Tillage Impact on Soil Biological Activity and Aggregation in a Brazilian Cerrado Oxisol. Soil \& Tillage Research, 92, 114-121. http://dx.doi.org/10.1016/j.still.2006.01.004

[15] Acosta-Martinez, V., Cruz, L., Sotomayor-Ramirez, D. and Perez-Alegria, L. (2007) Enzyme Activities as Affected by Soil Properties and Land Use in a Tropical Watershed. Applied Soil Ecology, 35, 35-45. http://dx.doi.org/10.1016/j.apsoil.2006.05.012

[16] Schnürer, J. and Rosswall, T. (1982) Fluorescein Diacetate Hydrolysis as a Measure of Total Microbial Activity in Soil and Litter. Applied and Environmental Microbiology, 43, 1256-1261.

[17] Van Elsas, J.D., Duarte, G.F., Rosado, A.S. and Smalla, K. (1998) Microbiological and Molecular Biological Methods for Monitoring Microbial Inoculants and Their Effects in the Soil Environment. Journal of Microbiological Methods, 32, 133-154. http://dx.doi.org/10.1016/S0167-7012(98)00025-6

[18] Nüsslein, K. and Tiedje, J.M. (1998) Characterization of the Dominant and Rare Members of a Young Hawaiian Soil Bacterial Community with Small-Subunit Ribosomal DNA Amplified from DNA Fractionated on the Basis of Its Guanine and Cytosine Composition. Applied and Environmental Microbiology, 64, 1283-1289.

[19] Griffiths, R.I., Whiteley, A.S., O’Donnell, A.G. and Bailey, M.J. (2003) Rapid Method for Coextraction of DNA and RNA from Natural Environments for Analysis of Ribosomal DNA and rRNA-Based Microbial Community Composition. Applied and Environmental Microbiology, 66, 5488-5491. http://dx.doi.org/10.1128/AEM.66.12.5488-5491.2000

[20] Ranjard, L., Poly, F. and Nazaret, S. (2000) Monitoring Complex Bacterial Communities Using Culture-Independent Molecular Techniques: Application to Soil Environment. Research in Microbiology, 151, 167-177. http://dx.doi.org/10.1016/S0923-2508(00)00136-4

[21] Stark, C.H., Condron, L.M., O’Callaghan, M., Stewart, A. and Di, H.J. (2008) Differences in Soil Enzyme Activities, Microbial Community Structure and Short-Term Nitrogen Mineralisation Resulting from Farm Management History and Organic Matter Amendments. Soil Biology \& Biochemistry, 40, 1352-1363. http://dx.doi.org/10.1016/j.soilbio.2007.09.025

[22] Kaur, K., Kapoor, K.K. and Gupta, A.P. (2005) Impact of Organic Manures with and without Mineral Fertilizers on Soil Chemical and Biological Properties under Tropical Conditions. Journal of Plant Nutrition and Soil Science, 168, 117-122. http://dx.doi.org/10.1002/jpln.200421442

[23] Liu, E., Yan, C., Mei, X., He, W., Bing, S.H., Ding, L., Liu, Q., Liu, S. and Fan, T. (2010) Long-Term Effect of Chemical Fertilizer, Straw, and Manure on Soil Chemical and Biological Properties in Northwest China. Geoderma, 158, 173-180. http://dx.doi.org/10.1016/j.geoderma.2010.04.029

[24] Mando, A., Ouattara, B., Sédogo, M., Stroosnijder, L., Ouattara, K., Brussaard, L. and Vanlauwe, B. (2005) LongTerm Effect of Tillage and Manure Application on Soil Organic Fractions and Crop Performance under Sudano-Sahelian Conditions. Soil \& Tillage Research, 80, 95-101. http://dx.doi.org/10.1016/j.still.2004.03.002

[25] Fontes, J. and Guinko, S. (1995) Carte de la végétation et de l’occupation du sol du Burkina Faso. Note Explicative. Ministère de la coopération française, Toulouse.

[26] FAO (2006) World Reference Base for Soil Resources 2006: A Framework for International Classification, Correlation and Communication, World Soil Resources Reports 103. FAO, Rome.

[27] Amato, M. and Ladd, J.N. (1988) Assay for Microbial Biomass Based on Ninhydrin-Reactive Nitrogen in Extracts of Fumigated Soils. Soil Biology \& Biochemistry, 20, 107-114. http://dx.doi.org/10.1016/0038-0717(88)90134-4 
[28] Hayano, K. (1973) A Method for Determination of $\beta$-Glucosidase Activity in Soil. Soil Science and Plant Nutrition, 19, 103-108. http://dx.doi.org/10.1080/00380768.1973.10432524

[29] Tabatabai, M.A. and Bremmer, J.M. (1969) Use of P-Nitrophenylphosphate for Essay of Soil Phosphatase Activity. Soil Biology \& Biochemistry, 1, 301-307. http://dx.doi.org/10.1016/0038-0717(69)90012-1

[30] Nannipieri, P., Ceccanti, C., Ceverlli, S. and Matarese, E. (1980) Extraction of Phosphatase, Urease, Protease, Organic Carbon and Nitrogen from Soil. Soil Science Society of America Journal, 44, 1011-1016. http://dx.doi.org/10.2136/sssaj1980.03615995004400050028x

[31] Adam, G. and Duncan, H. (2001) Development of a Sensitive and Rapid Method for the Measurement of Total Microbial Activity Using Fluorescein Diacetate (FDA) in a Range of Soils. Soil Biology \& Biochemistry, 33, 943-951. http://dx.doi.org/10.1016/S0038-0717(00)00244-3

[32] Hai, B., Diallo, N.H., Sall, S., Felix, H., Schauss, K., Bonzi, M., Assigbetse, K., Chotte, J.L., Munch, J.C. and Schloter, M. (2009) Quantification of Key Genes Steering the Microbial Nitrogen Cycle in the Rhizosphere of Sorghum Cultivars in Tropical Agroecosystems. Applied and Environmental Microbiology, 75, 4993-5000. http://dx.doi.org/10.1128/AEM.02917-08

[33] Ovreas, L., Forney, L., Daae, F.L. and Torsvik, V. (1997) Distribution of Bacterioplankton in Meromitic Lake Saelenvannet, as Determined by Denaturing Gradient Gel Electrophoresis of PCR-Amplified Gene Fragments Coding for 16S rRNA. Applied and Environmental Microbiology, 63, 3367-3373.

[34] Muyzer, G., Waal, E.C.D. and Uitterlinden, A.G. (1993) Profiling of Complex Microbial Populations by Denaturing Gradient Gel Electrophoresis Analysis of Polymerase Chain Reaction-Amplified Genes Coding for 16S rRNA. Applied and Environmental Microbiology, 59, 695-700.

[35] Shannon, C.E. and Weaver, W. (1963) The Mathematical Theory of Communication. University of Illinois Press, Urbana.

[36] Mandal, A., Patra, A.K., Singh, D., Swarup, A. and Masto, R.E. (2007) Effect of Long-Term Application of Manure and Fertilizer on Biological and Biochemical Activities in Soil during Crop Development Stages. Bioresource Technology, 98, 3585-3592. http://dx.doi.org/10.1016/j.biortech.2006.11.027

[37] Enwall, K., Nyberg, K., Bertilsson, S., Cederlund, H., Stenstrom, J. and Hallin, S. (2007) Long-Term Impact of Fertilization on Activity and Composition of Bacterial Communities and Metabolic Guilds in Agricultural Soil. Soil Biology \& Biochemistry, 39, 106-115. http://dx.doi.org/10.1016/j.soilbio.2006.06.015

[38] Wen, Y.L., Xiao, J., Li, H., Shen, Q.R., Ran, W., Zhou, Q.S. and Yu, G.H. (2014) Long-Term Fertilization Practices Alter Aluminnjum Fractions and Coordinate State in Soil Colloids. Soil Science Society of America Journal, 78, 20832089. http://dx.doi.org/10.2136/sssaj2014.04.0147

[39] Hati, K.M., Swarup, A., Mishra, B., Manna, M.C., Wanjari, R.H., Mandal, K.G. and Misra, A.K. (2008) Impact of Long-Term Application of Fertilizer, Manure and Lime under Intensive Cropping on Physical Properties and Organic Carbon Content of an Alfisol. Geoderma, 148, 173-179. http://dx.doi.org/10.1016/j.geoderma.2008.09.015

[40] Ge, G., Li, Z., Fan, F., Chu, G., Hou, Z. and Liang, Y. (2010) Soil Biological Activity and Their Seasonal Variations in Responsible to Long-Term Application of Organic and Inorganic Fertilizers. Plant and Soil, 326, 31-44. http://dx.doi.org/10.1007/s11104-009-0186-8

[41] Hassink, J., Lebbink, G. and Van Veen, J.A. (1991) Microbial Biomass and Activity of a Reclaimed-Polder Soil under a Conventional or a Reduced-Input Farming System. Soil Biology \& Biochemistry, 23, 507-513. http://dx.doi.org/10.1016/0038-0717(91)90107-U

[42] Küsel, K. and Drake, H.L. (1999) Microbial Turnover of Low Molecular Weight Organic Acids during Leaf Litter Decomposition. Soil Biology \& Biochemistry, 31, 107-118. http://dx.doi.org/10.1016/S0038-0717(98)00111-4

[43] Calbrix, R., Barray, S., Chabrerie, O., Fourrie, L. and Laval, K. (2007) Impact of Organic Amendments on the Dynamics of Soil Microbial Biomass and Bacterial Communities in Cultivated Land. Applied Soil Ecology, 35, 511-522. http://dx.doi.org/10.1016/j.apsoil.2006.10.007

[44] Pascual, J.A., Garcia, C., Hernandez, T. and Ayuso, M. (1997) Changes in the Microbial Activity of an Arid Soil Amended with Urban Organic Wastes. Biology and Fertility of Soils, 24, 429-434. http://dx.doi.org/10.1007/s003740050268

[45] Kong, W.D., Zhu, Y.G., Fu, B.J., Han, X.Z., Zhang, L. and He, J.Z. (2008) Effect of Long-Term Application of Chemical Fertilizers on Microbial Biomass and Functional Diversity of a Black Soil. Pedosphere, 18, 801-808. http://dx.doi.org/10.1016/S1002-0160(08)60076-4

[46] Li, J., Zhao, B.Q., Li, X.Y., Jiang, R.B. and Bing, S.H. (2008) Effects of Long-Term Combined Application of Organic and Mineral Fertilizers on Microbial Biomass, Soil Enzyme Activities and Soil Fertility. Agricultural Sciences in China, 7, 336-343. http://dx.doi.org/10.1016/S1671-2927(08)60074-7

[47] Houot, S. and Chaussod, R. (1995) Impact of Agricultural Practices on the Size and Activity of the Microbial Biomass 
in a Long-Term Field Experiment. Biology and Fertility of Soils, 19, 309-316. http://dx.doi.org/10.1007/BF00336100

[48] Ros, M., Garcia, C. and Hernandez, T. (2003) Soil Microbial Activity after Restoration of a Semiarid Soil by Organic Amendments. Soil Biology \& Biochemistry, 35, 463-469. http://dx.doi.org/10.1016/S0038-0717(02)00298-5

[49] Sánchez-Monedero, M.A., Mondini, C., Cayuela, M.L., Roig, A., Contin, M. and De Nobili, M. (2008) Fluorescein Diacetate Hydrolysis, Respiration and Microbial Biomass in Freshly Amended Soils. Biology and Fertility of Soils, 44, 885-890. http://dx.doi.org/10.1007/s00374-007-0263-1

[50] Dick, R.P. (1997) Soil Enzyme Activities as Integrative Indicators of Soil Health. In: Pankhurst, C.E., Doube, B.M. and Gupta, V.V.S.R., Eds., Biological Indicators of Soil Health, CAB International, Wallingford, 121-157.

[51] Taylor, J.P., Wilson, B., Mills, M.S. and Burns, R.G. (2002) Comparison of Microbial Numbers and Enzymatic Activities in Surface Soils and Subsoils Using Various Techniques. Soil Biology \& Biochemistry, 34, 387-401. http://dx.doi.org/10.1016/S0038-0717(01)00199-7

[52] Jensen, L.E. and Nybroe, O. (1999) Nitrogen Availability to Pseudomonas fluorescens DF57 Is Limited during Decomposition of Barley Straw in Bulk Soil and in the Barley Rhizosphere. Applied and Environmental Microbiology, 65, 4320-4328.

[53] Nannipieri, P.J., Ascher, M.T., Ceccherini, L., Landi Pietramellara, G. and Renella, G. (2003) Microbial Diversity and Soil Functions. European Journal of Soil Science, 54, 655-670. http://dx.doi.org/10.1046/j.1351-0754.2003.0556.x

[54] Crecchio, C., Curci, M., Pizzigallo, M.D.R., Ricciuti, P. and Ruggiero, P. (2004) Effects of Municipal Solid Waste Compost Amendments on Soil Enzyme Activities and Bacterial Genetic Diversity. Soil Biology \& Biochemistry, 36, 1595-1605. http://dx.doi.org/10.1016/j.soilbio.2004.07.016

[55] Drissner, D., Blum, H., Tscherko, D. and Kandeler, E. (2007) Nine Years of Enriched $\mathrm{CO}_{2}$ Changes the Function and Structural Diversity of Soil Microorganisms in a Grassland. European Journal of Soil Science, 58, 260-269. http://dx.doi.org/10.1111/j.1365-2389.2006.00838.x

[56] Bi, L., Zhang, B., Liu, G., Li, Z., Liu, Y., Ye, C., Yu, X., Lai, T., Zhang, J., Yin, J. and Liang, Y. (2009) Long-Term Effects of Organic Amendments on the Rice Yields for Double Rice Cropping Systems in Subtropical China. Agriculture, Ecosystems \& Environment, 129, 534-541. http://dx.doi.org/10.1016/j.agee.2008.11.007

[57] Singh, Y., Singh, B., Maskina, M.S. and Meelu, O.P. (1988) Effect of Organic Manures, Crop Residues and Green Manure (Sesbania aculeata) on Nitrogen and Phosphorus Transformations in a Sandy Loam at Field Capacity and under Waterlogged Conditions. Biology and Fertility of Soils, 6, 183-187.

[58] Kaewpradit, W., Toomsan, B., Cadisch, G., Vityakon, P., Limpinuntana, V., Saenjan, P., Jogloy, S. and Patanothai, A. (2008) Regulating Mineral N Release by Mixing Groundnut Residues and Rice Straw under Field Conditions. European Journal of Soil Science, 59, 640-652. http://dx.doi.org/10.1111/j.1365-2389.2008.01021.x

[59] Gaur, A.C. and Pareek, R.P. (1974) Organic Acids in Soil during Degradation of Organic Residues. Proceedings of the Indian National Science Academy, Part B, 40, 68-76.

[60] Nelson, C.J. (1996) Allelopathy in Cropping Systems. Agronomy Journal, 88, 853. http://dx.doi.org/10.2134/agronj1996.00021962003600060002x

[61] Azam, F., Lodhi, A. and Ashraf, M. (1991) Availability of Soil and Fertilizer Nitrogen to Wetland Rice Following Wheat Straw Amendment. Biology and Fertility of Soils, 11, 97-100. http://dx.doi.org/10.1007/BF00336371

[62] Verma, T.S. and Bhagat, R.M. (1992) Impact of Rice Straw Management Practices on Yield, Nitrogen Uptake and Soil Properties in a Wheat-Rice Rotation in Northern India. Fertilizer Research, 33, 97-106.

http://dx.doi.org/10.1007/BF01051164 